\title{
Some Fresh Air into the Neopythagorean Tradition: The Fragments On Kingship by Diotogenes*
}

abstract: The Neopythagorean Diotogenes, author of a lost treatise On Kingship of which some fragments have come down to us in Stobaeus' Anthology, is a largely neglected writer. Scholars either ignore him or briefly discuss him in the context of general overviews of Greek political thinking, usually comparing him to other Neopythagoreans like Sthenidas and Ecphantus. This article argues that Diotogenes deserves to be read for his own sake, as a creative and subtle thinker who managed to contribute to his own philosophical tradition by benefitting from Homer exegesis and by taking into account the demands of concrete life.

1. Diotogenes: unknown, unloved

The name of Diotogenes does not immediately ring a bell, not even among classicists. He is a Neopythagorean thinker whose works have all been lost, except for a few fragments that have been preserved in Stobaeus' Anthology. We still have three fragments from a treatise On piety and two longer excerpts from a treatise On kingship. ${ }^{1}$ The author himself is entirely unknown: we only have his name, and even that is not certain. For as a matter of fact, the name itself is

\footnotetext{
* I am much indebted to all the participants of the different Journées d'étude devoted to the Neopythagorean treatises On kingship in Paris, and to Myrto Hatzimichali and to the two anonymous referees of this journal, whose comments on an earlier draft of this article helped me a lot in clarifying my position.

${ }^{1}$ The fragments from On piety are to be found in Stobaeus 3.1.100, 4.1.96, and 4.1.133, those from On kingship in 4.7.61 and 4.7.62. I use the most recent edition of Thesleff (1965); the translations are borrowed from Goodenough (1928), sometimes with slight modifications.
} 
unparalleled in extant ancient sources ${ }^{2}$ and several scholars have suggested alternatives like Diogenes or (the equally unparalleled) Diaetogenes. ${ }^{3}$ Diotogenes' date is likewise a matter of speculation. The fragments from his works do not contain any clear information that could provide us with a terminus post or ante quem, and as a result, opinions on the date greatly differ. Some specialists favour a relatively early date in the Hellenistic period (third century BC), ${ }^{4}$ others are convinced that Diotogenes lived in a period between the first century BC and the first century $\mathrm{AD},{ }^{5}$ and yet others prefer an even later date, in the early imperial period (first or second century AD). ${ }^{6}$ The few scraps of a recently edited papyrus (P.Bingen 3 ) which may contain a fragment from Diotogenes' treatise on Kingship are of little help, since the precise relation between the two texts is far from clear. ${ }^{7}$ We mainly have to rely on a careful linguistic analysis of Diotogenes' artificial Doric and on a study of the occurrence of parallel ideas in other authors. But such studies do not yield compelling evidence, ${ }^{8}$ and a prudent non liquet seems to be the only possible conclusion of this long scholarly debate.

In light of all these problems, it is perhaps not surprising that Diotogenes' thinking has received only little attention in scholarly research. Particularly illustrative in this respect is the

\footnotetext{
${ }^{2}$ There is not one single parallel listed in the LGPN of Fraser - Matthews (1987-2013).

${ }^{3}$ See Delatte (1942) 283.

${ }^{4}$ E.g. Goodenough (1928); Thesleff (1961); Martens (2003).

${ }^{5}$ Zeller (1903) 123; Murray (1970) 280; Centrone (2014) 339.

${ }^{6}$ Delatte (1942); Squilloni (1991); Virgilio (2003) 64.

${ }^{7}$ See Andorlini - Luiselli (2001), who argue that Diotogenes is the source of the papyrus. However, the very few words on the papyrus that can be clearly read do not allow firm conclusions. The whole case indeed mainly rests on the presence of the term $\vartheta \varepsilon o \mu\{\varepsilon\} \uparrow \mu$ in the first line of the papyrus. Daris (2000) 16, who prepared the editio princeps of the papyrus, reads $\dot{\varepsilon} \sigma o \mu \varepsilon^{\prime} \nu[\eta \varsigma$.

${ }^{8}$ Cf. Thesleff (1961) 65-7.
} 
article in the Realencyclopädie, which consists of only six lines. ${ }^{9}$ Several more general studies of the ideology of kingship briefly discuss Diotogenes, usually relating him to other Neopythagorean authors like pseudo-Archytas and especially Sthenidas and Ecphantus. ${ }^{10}$ The latter two have also written treatises On kingship which have been lost, except for a few fragments preserved in Stobaeus. ${ }^{11}$ Although they are not better known that Diotogenes, a comparison of the three authors reveals several interesting parallels and in that sense, one obscurum may at least throw some opaque light on another one. Centrone has pushed such a comparative approach to an extreme, by combining various elements taken from different Neopythagorean authors in order to reconstruct one coherent political doctrine. ${ }^{12}$ His view has much to commend it. It radically and quite consistently pursues the consequences of a widespread implicit tendency that exists in the scholarly research on the Neopythagorean fragments. Moreover, it indeed gives a good idea of the general orientation of the political thinking that can be found in these Neopythagorean treatises On kingship. Of central importance is, of course, the figure of the king, who occupies an intermediate position between God and his subjects. The king should himself imitate God and therefore aims at (or even already gives

\footnotetext{
${ }^{9}$ Wellmann (1903). The article in the DPhA runs to thirteen lines; Centrone (1994).

10 See, e.g., Kagan (1965) 246-9; Murray (1970) 245-83; Aalders (1975) 27-8; Chesnut (1978) 1313-20; Giannantoni (1982) 357-62; Schulte (2001) 136-48; Muccioli (2002) 361-5; Virgilio (2003) 63-5; Desmond (2011) 57-8. Diotogenes is not even mentioned in several recent overviews of ancient Greek political thought, such as Salkever (2009). In Balot (2009), he is only mentioned in passing on p. 274-5 and 277.

${ }^{11}$ Stobaeus 4.7.63 (Sthenidas) and 4.6.22, 4.7.64, 4.7.65, and 4.7.66 (Ecphantus); the fragments are edited by Delatte (1942) 25-37 and 45-6 and by Thesleff (1965) 79-84 and 187-8. Ecphantus' position has received most attention; see esp. Squilloni (1991); cf. Calabi (2008) 185-215 on parallels between Ecphantus and Philo of Alexandria.

${ }^{12}$ Centrone (2014) 333-6; cf. already Thesleff (1961) 73 on the "comparatively homogeneous character" of the Neopythagorean writings.
} 
evidence of $)^{13}$ perfect virtue. As such, he can himself act as a model for his subjects and finally establish in his kingdom a harmony that conforms to the harmony of the universe. This, as Centrone has shown very well, is the core of the Neopythagorean political doctrine.

Yet such general reconstructions also entail an obvious methodological problem, in that they fail to do justice to the specificity of every singular author. ${ }^{14}$ Even if Centrone's main hypothesis is correct that the different treatises all rest on a single coherent philosophical system, it remains true that the various authors still lay their own accents. Most scholars agree that Ecphantus has a different profile from Diotogenes and that he is the more interesting of the two. ${ }^{15}$ In this article, I would like to redress the balance. I claim indeed that a careful reading of the two fragments from Diotogenes' treatise On kingship shows that he was an ingenious and sophisticated political thinker who was able to creatively contribute to his own philosophical tradition. This view also challenges an important presupposition in existing scholarship on the Neopythagorean treatises On kingship, viz. that they were not meant to be innovative at all and merely had a repackaging function, summarizing existing ideas with only a superficial Pythagorean colouring. In this paper, I hope to show that this presupposition is not always justified and that a careful and detailed interpretation of the fragments, which gives due attention to the authors' use of particular concepts and argumentative techniques, tells a different story.

\footnotetext{
${ }^{13}$ The Neopythagoreans usually adopt a normative perspective, yet some passages suggest in a more descriptive vein that the king is already virtuous; see, e.g., Diotogenes, fr. 1 (p. 71.21-3; cf. infra section 4) and Ecphantus, fr. 2 (p. 8.1-7 and 81.9-13).

${ }^{14}$ Cf. Bonazzi (2013) 385.

${ }^{15}$ As a rule, Ecphantus is more appreciated and regarded as more 'mystical' than Diotogenes; see, e.g., Delatte (1942) 290; Murray (1970) 266 and (2007) 21; Squilloni (1991) 72. I'll come back to this evaluation at the end of this article.
} 
2. Fragment 1: Diotogenes and the Homeric king

The first fragment opens with an emphasis on the close connection between kingship, justice and the law (p. 71.18-23). This already provides a first illustration of Diotogenes' subtle thinking and I shall deal with it extensively in due course. But since a correct understanding of this passage requires a better insight into Diotogenes' heuristic strategies and authorial approach, I prefer to deal with it later (see section 4).

After this opening passage, Diotogenes distinguishes three main tasks of the king:

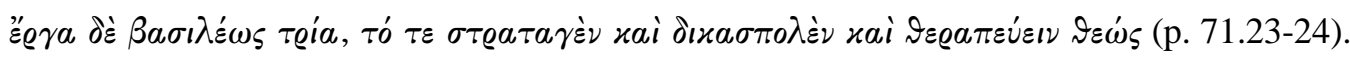

The duties of the king are threefold, military leadership, the dispensation of justice, and the cult of the gods.

At first sight, these three tasks seem to be mere commonplaces which return in many other authors as well. ${ }^{16}$ Yet such parallels conceal as much as they reveal. For while we indeed have parallels for each of these activities, we do not find this threefold combination elsewhere in the same form. What still needs to be done, then, is to assess the theory as a whole and to see whether it is possible to find its origins.

A first key to a better understanding of this theory is the term $\delta \varkappa \varkappa \sigma \pi 0 \lambda \varepsilon \dot{\varepsilon}$. This is a fairly rare term with a clear Homeric stamp. Homer himself uses the term twice. In Iliad book 1, Agamemnon points out that the sceptre is held by the sons of the Achaeans who judge (virs

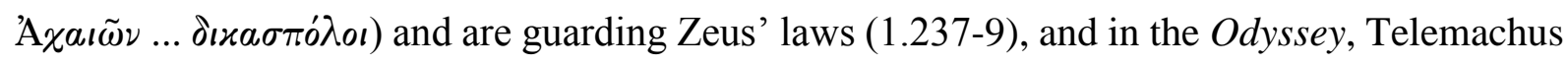

\footnotetext{
${ }^{16}$ Parallels can be found in Delatte (1942) 249-55.
} 


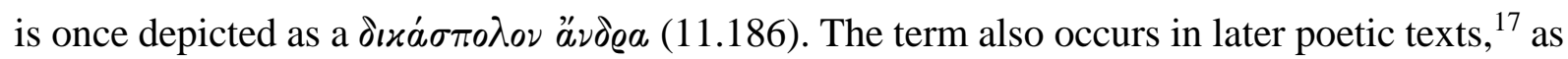
a clear reminiscence of Homer, and is explained in the scholia on Homer. In the D-Scholia on

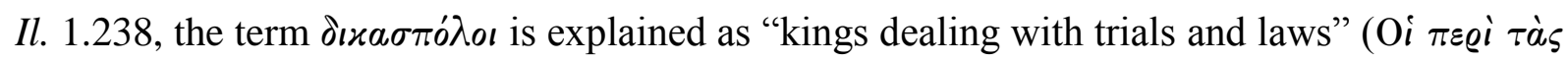

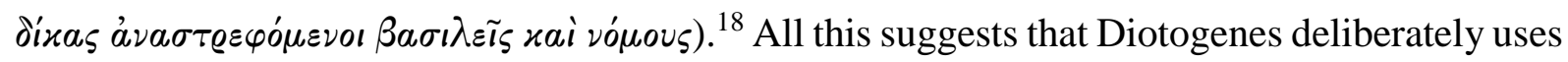
the term $\delta \iota x \sigma \pi \circ \lambda \varepsilon \tilde{\imath} \nu$ as a clear reminiscence of Homer, even more so since the term occurs nowhere else in extant prose texts about political philosophy. An erudite ancient reader, then, would connect Diotogenes' discussion of the king's tasks with the picture of the Homeric king. If that is true, this aspect of Diotogenes' political thinking may well be ultimately rooted in Homer exegesis rather than in the rich tradition of political philosophy. ${ }^{19}$

Now that the verb $\delta \varkappa a \sigma \pi \circ \lambda \varepsilon \varepsilon \tilde{i}$ has provided an interesting indication regarding Diotogenes' source of inspiration, we may have a fresh look at the other two tasks of the king and examine whether these can also be related to the image of the Homeric king. This requires further study of the ancient scholia on Homer, which contain the germs of a certain reflection on kingship. And it is hardly surprising that the two tasks mentioned by Diotogenes indeed return in the scholia as well. That the king should be an excellent general is obvious of course in a Homeric context. After all, Homer characterizes Agamemnon as "a good king and a strong spearman"

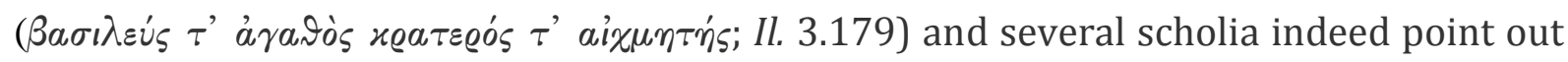
that kings need military qualities..$^{20}$ The most interesting for our purposes is Schol. in Il.

\footnotetext{
${ }^{17}$ See, e.g., Callimachus, Hymn. 1,3 and Apollonius of Rhodes, 4.1178. It is also used by later authors such as Quintus (5.172; 5.176) and especially Nonnus (D. 5.595; 6.249; 19.234; 33,76; 36.126; 41.171; 41.275; 43.126); cf. also several poems in the Greek Anthology (5.274.6; 7.334.10; 7.573.3; 8.108.1; 9.705.1; 11.376.2; 16.43.1).

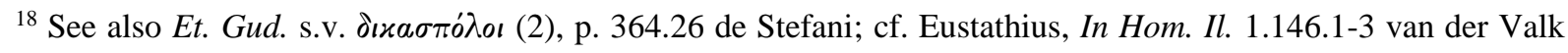
and Hesychius, Lex. $\Delta 1798$ Latte.

${ }^{19}$ Postponing for the time being the question as to whether Diotogenes used intermediary sources.

${ }^{20}$ See, e.g., Schol. in Il. 9.709b and 10.407b; cf. 3.179; 4.95; 8.117.
} 
2.207a, where the task of controlling the army is considered one of the kingly tasks ( $\beta a \sigma ı \lambda ı x \grave{a}$ Éera). The king's relation to the world of the gods receives no less attention in the scholia, which reflects the Homeric conviction that kingship is given by Zeus. ${ }^{21}$ Just as Diotogenes regards the task of the king as serving the gods (จะ@a

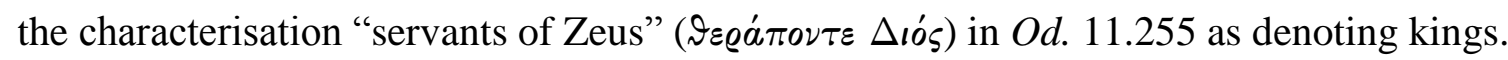

All of these parallels seem to suggest that Diotogenes fashions his own ideal of the good king after the Homeric tradition. If that is indeed the case, we come across a distinct approach that has no parallel whatsoever in the extant fragments from Sthenidas and Ecphantus and that yields several new conclusions.

Firstly, this fragment from Diotogenes gains importance for the rich reception history of Homer, as it adds a new example of ancient thinking about kingship by means of Homer. The above quoted parallels from the scholia on Homer do not yet reflect a systematic doctrine of kingship, ${ }^{22}$ but are usually given $a d$ loc. and ad hoc. Yet they rest on the firm conviction that both Iliad and Odyssey contain several ideas that may be relevant for kings. ${ }^{23}$ Many passages

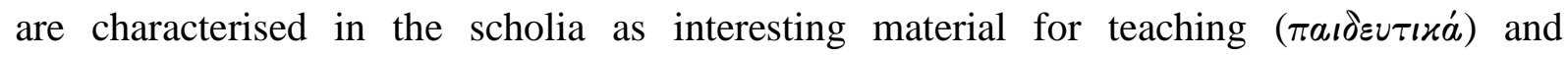
occasionally the scholiast even makes it explicit that he is especially thinking of royal pupils

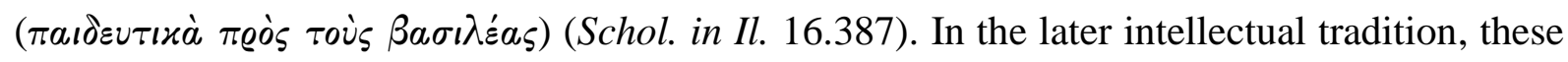
exegetical observations were further elaborated and systematised, as is illustrated by works such

\footnotetext{
${ }^{21}$ See, e.g., Schol. in Il. 1.281; 2.205a; on the link between the king and the gods, see also Schol. in Il. 1.9; 1.176; $2.197 \mathrm{a} ; 3.364-5 ; 4.51-2$.

${ }^{22}$ Although some traces of systematisation can already be found; see, e.g., Schol. in Od. 2,47, where it is said that

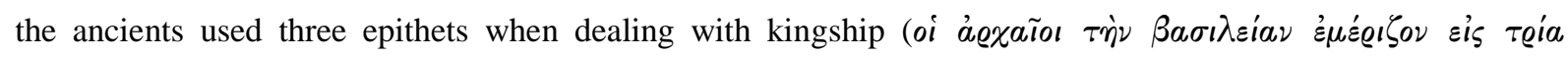

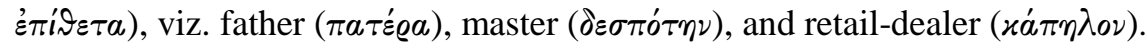

${ }^{23}$ This conviction may at least go back to the fourth century BC, as is suggested by Xenophon, Smp. 4.6.
} 
as Philodemus' On the good king according to Homer, several speeches of Dio of Prusa, ${ }^{24}$ and Porphyry's lost monumental work in ten books On the benefit for kings from Homer (Suda, 4.178.27 Adler). These works should be understood against the background of an age-long tradition of political thinking. They combine elements of Plato's ideal of the philosopher-king with Aristotelian and Stoic material (or rely, in Philodemus' case, on traditional Epicurean thoughts) and connect the resulting doctrine with carefully selected Homeric material. In that way, the different authors could use Homer as an important argumentatum ex auctoritate for their own position.

Secondly, Diotogenes' use of Homer is not only interesting in light of the tradition of ancient Homer exegesis but also illustrates his creative approach towards his own philosophical tradition. Scholarly research has shown that the Neopythagoreans were among the intellectual heirs of Plato's Academy. It was probably in the Academy that Pythagoras' thinking was first introduced and brought into conformity with Plato's philosophy. ${ }^{25}$ In the later history of Platonism, the differences between the Platonic and the Pythagorean point of view were often hard to see, and the Neopythagoreans are now often even considered as Platonists. ${ }^{26}$ They

\footnotetext{
${ }^{24}$ On Philodemus, see, e.g., Murray (1965); Dorandi (1982); Asmis (1991) and Fish (2002). As to Dio of Prusa, esp. relevant are Orat. 1 and 2; cf. also 3.9; 4.39-45; 53.11-12; 56; 57. Other thinkers also used Homeric material in order to elaborate their conception of good rulership. Philo of Alexandria, for instance, repeatedly recalls the

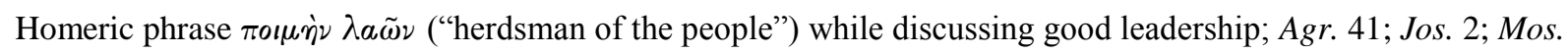
1.61; Prob. 31. See further Buffière (1973) 343-59 on ancient Homer exegesis concerning Homer's supposed preference for monarchy and his view of the different tasks of the king.

${ }^{25}$ See, e.g., Kahn (2001) 63-71; Dillon (2014) 251-60; cf. Bonazzi (2013) 389.

${ }^{26}$ See, e.g., Riedweg (2005) 124-25 ("In a certain sense, Neo-Pythagoreanism can be seen as a variety or even as a "denomination" within the Platonism of the imperial age"); Bonazzi (2013) 400 ("If my reconstruction is correct, the pseudo-Pythagorean treatises emerge as belonging more to Platonism than to Pythagoreanism [perhaps as a further chapter in the history of the Platonic-Academic appropriation of Pythagoreanism]"); Centrone (2014) 337
} 
developed their own 'Pythagorean' views by means of basically Platonic concepts and ideas, supplementing them with Aristotelian material.

As a matter of fact, we may well wonder whether Aristotle's influence can be felt in this fragment from Diotogenes as well. In the third book of his Politics, Aristotle distinguishes different forms of kingship. In his view, Homeric kingship consists of three principal components: the king had the authority in war, controlled all the sacrifices that were outside the scope of the priestly class, and passed judgement in law-suits (1285b9-11). In other terms, the king acted as a general ( $\sigma \tau \varrho a \tau \eta \gamma o ́ \varsigma)$, a judge (

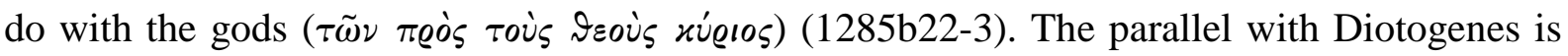
clear, and this indeed raises the obvious question as to whether we need Homer at all for our understanding of Diotogenes' view of kingship. Is it not easier and more economic to regard Aristotle as Diotogenes' direct source, rather than the tradition of Homeric exegesis?

On closer inspection, that would be a too rash conclusion, for the matter appears to be more complicated. After analysing the different kinds of kingship (heroic kingship, barbarian kingship, elective tyranny, Spartan kingship, and absolute monarchy), Aristotle concludes that all these can fundamentally be reduced to two types, viz. the Spartan kingship and absolute monarchy (1285b33-5). These may be studied in further detail, whereas the other ones (including the Homeric variant) are left behind. Hence, precisely what Aristotle prefers to dismiss as less interesting for philosophical discussion, constitutes the core of Diotogenes' conception of the ideal king. If Diotogenes indeed takes Aristotle's position into account, his reaction should be understood as a polemical one. In his view, Aristotle would then have made

\footnotetext{
("It is preferable then to describe the authors of the apocrypha as Pythagoreanizing Platonists, who considered themselves to be heirs to the Pythagorean tradition, with a firm belief in the continuity between Pythagoras, Plato and Aristotle"); Dillon (2014) 250 ("Neopythagoreans were Platonists and not themselves directly affiliated to anything that could be described as a Pythagorean 'school”').
} 
the wrong selection. Not Spartan kingship or absolute monarchy, but the Homeric ideal of kingship deserves further discussion. Furthermore, Aristotle uses the much more common term

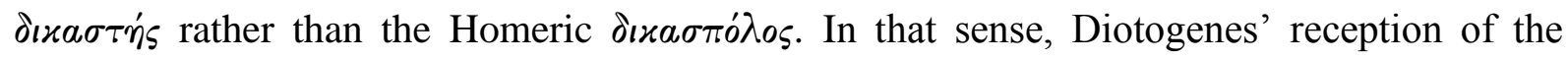
Homeric conception of the king shows in any case more Homeric flavour than that of Aristotle, and presupposes a familiarity with Homer that could not be derived as such from Aristotle's discussion in Politics 3. We may conclude, then, that it is far from certain whether Diotogenes has ever read Aristotle and that, even if Aristotle's Politics was among Diotogenes' sources, it was definitely not his only one.

The above analysis has shown that Diotogenes further develops traditional Academic thinking about the ideal ruler (ultimately rooted in Plato's ideal of the philosopher-king, enriched with Aristotelian elements) by connecting it with ideas gained from previous Homer exegesis. This, however, is not the whole story. What has been neglected so far is the Pythagorean aspect of Diotogenes' position. That is part and parcel of his theory as well, for we see that he takes care to give his more concrete elaboration of the king's three tasks a Pythagorean colour. The king's role as a general is clarified from the general perspective of the ruler's particular ‘system’ ( $\sigma \dot{\sigma} \sigma a \mu a)$ (p. 72.6-9).

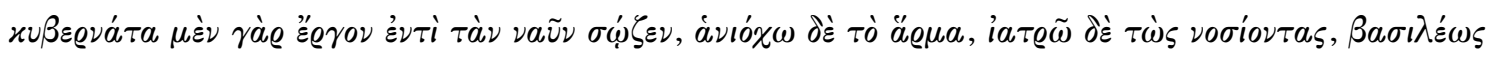

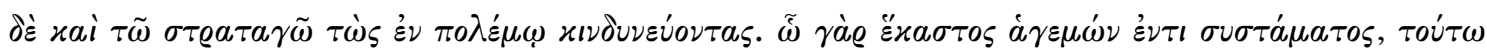

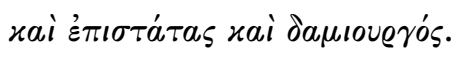

For the task of a pilot is to save the ship, of the charioteer to save the chariot, of a physician to save those who are ill, while the task of the king and captain is to save those who are in danger in war. For each of these is overseer and craftsman of the organization of which he is the ruler.

The word $\sigma \dot{\sigma} \sigma \tau \mu \mu a$ is a key term that repeatedly occurs in other Neopythagorean thinkers as 
well ${ }^{27}$ and gives Diotogenes' view a more Pythagorean touch. The king's duty as a judge also requires an imitation of God: just as God rules the universe, so the king will bring about

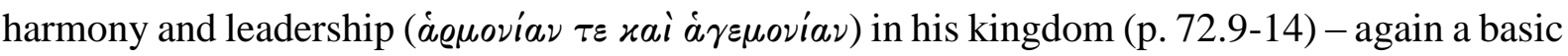
idea that reappears in other Neopythagoreans as well. ${ }^{28}$ Moreover, the notion of harmony plays an important part here. Of course this concept was not a monopoly of the Pythagorean tradition - Platonists were fond of the term too ${ }^{29}$ - but it is part and parcel of reconstructed Pythagorean thinking and could be recognised as such by the ancient reader. When dealing with the third task of the king, that is, his priestly function, Diotogenes returns to the same idea and elaborates it in terms that express the idea of proportion: the king has the same relation to the state as God has to the universe, and the state has the same relation to the universe as the king has to God:

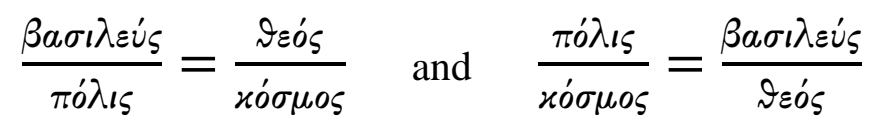

Once again, a traditional idea is thus rephrased in a way that suggests a Pythagorean approach informed by mathematical interests, although it should be added that the way proportion is here invoked by Diotogenes has no distinctively Pythagorean edge to it (no numerical ratios, for instance, nor even any numbers). All in all, then, Pythagorean colouring can be found throughout the fragment, although it is not developed into substantive Pythagorean ideas that are opposed to what can be found in other philosophical traditions.

The question remains whether this Pythagorean input comes from Diotogenes himself or

\footnotetext{
27 The parallels can be found in Delatte (1942) 251-2.

${ }^{28}$ See, e.g., Sthenidas, p. 188.7-10 and Ecphantus, fr. 2, 81.21-2 and 82.1-3; cf. Schulte (2001) 141 ("Diese Auffassung zeigt unverkennbar pythagoreische Merkmale”).

${ }^{29}$ A $T L G$ search lists 116 occurrences of á $\varrho$ ovía and related words in Plutarch, 47 in Plotinus, 77 in Porphyry, 449 in Proclus, and 132 in Damascius.
} 
whether it could already be found in an earlier tradition. An interesting scholion on Homer's Iliad 1,339-40a suggests that the Pythagorean tradition was also incorporated in ancient Homer exegesis. The commentator points out that Homer already before the Pythagoreans regarded the kingly nature as an intermediate nature, placed between men and God. This piece of Homeric scholarship obviously presumes a Pythagorean theory of monarchy that is very well in line with the position of Diotogenes. The problem is that we are uncertain about the date of the scholion: it cannot be excluded that it should be traced back to Porphyry's Homeric studies, ${ }^{30}$ but the learned Porphyry was probably familiar with age-old insights. Whether Diotogenes was heir to these traditional insights or rather helped to create them, must in the end remain an open question.

However that may be, the whole passage provides a telling illustration of creative political thinking that refigures Platonic-Academic and Aristotelian material in the light of traditional Homer exegesis and 'Pythagorean' elements. These different components are harmoniously combined and together make up a new theory that can claim the authoritative support of an ageold intellectual tradition and yet, as will become clear below, is far from fossilized or outdated.

\section{Fragment 2: Diotogenes and political pragmatism}

In the second, longer fragment, Diotogenes expatiates upon the king's virtues and moral qualities. It opens as follows (p. 72.25-29):

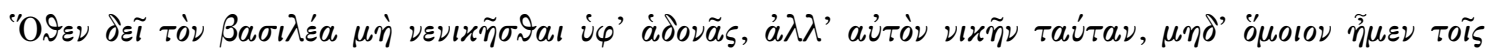

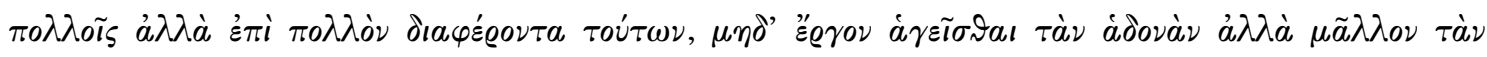

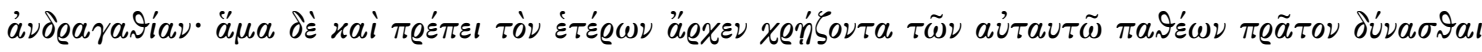

\footnotetext{
${ }^{30}$ Cf. Delatte (1942) 285.
} 
äexะv.

Wherefore the king must not be conquered by pleasure, but must himself conquer it. He must not resemble the multitude (indeed, he should be far different from them), and he must regard not pleasure but manly virtue as his proper objective. At the same time it is proper that one who desires to rule over others should first be able to rule over his own passions.

The king, then, should control his pursuit of pleasure (p. 72.25-8) and his greed (p. 72.29-73.1). His rule should rest on his virtue (p. 73.1-4), and he can only be a model for his subjects if he has first set his own character right. Again, we are here dealing with traditional ideas. Many parallels can be found in later authors ${ }^{31}$ and in literature Пвœi $\beta a \sigma i \lambda \varepsilon i a \varsigma$, and most of the ideas also occur in the scholia on Homer. ${ }^{32}$ But in this case as well, such single parallels fail to do justice to the peculiarity of Diotogenes' political philosophy.

In this fragment, we also find a trichotomy, now listing the three major qualities of the king (p. 73.19-28):

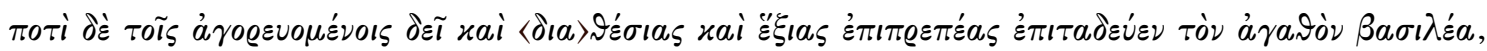

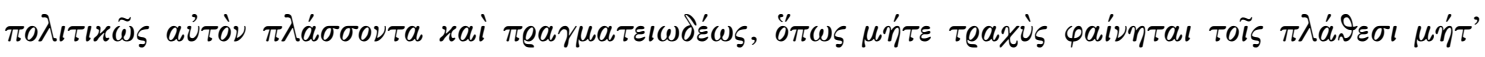

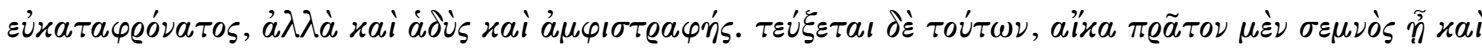

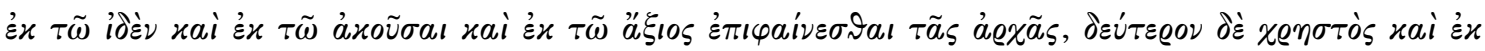

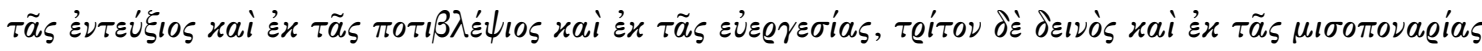

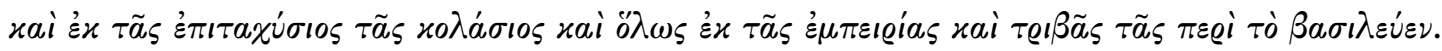

And besides issuing public decrees the good king should present to the state proper attitudes in body

\footnotetext{
${ }^{31}$ Delatte (1942) 256-63 again provides much relevant material. On parallels with later Middle-Platonic authors (such as Plutarch, esp. his treatise Ad principem ineruditum), see Squilloni (1991).

${ }^{32}$ See, e.g., Schol. in Il. 2.588 on the idea of the king controlling himself; $16.446-7$ on the king as a model for his subjects; Schol. in Od. 4.690 on the just king; etc.
} 
and mind. He should impersonate the statesman and have an appearance of practicality so as not to seem to the mob as either harsh or despicable, but at once pleasant and yet watchful from every angle. And he will succeed in this if first he make an impression of majesty by his appearance and utterances, and by his looking the part of the ruler; if secondly, he be gracious both in conversation and in appearance, and in actual benefactions; and third, if he inspire fear in his subjects by his hatred of evil and by his punishments, by his speed of action and in general by his skill and industry in kingly duties.

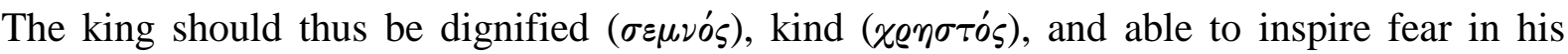

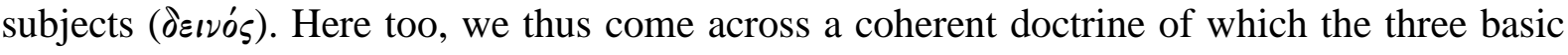
components are first introduced (p. 73.23-8) and then further elaborated (p. 73.28-75.16). ${ }^{33}$ These repeated systematic trichotomies show Diotogenes' pointedly pedagogical approach. His argument is very well structured, with clear introductions, elaborations, and final conclusions. He really takes his reader by the hand and efficiently guides him through the different steps of his argument. This observation raises the question of Diotogenes' intended reader. This, however, is a complicated issue. Some scholars consider his treatise On Kingship as an esoteric text or a kind of handbook "designed to fill a gap in the Pythagorean library, to complete the canon." 34 From such a perspective, Diotogenes' fondness for systematisation reflects a scholastic approach. His clarity is that of the schoolteacher. Others regard the work as exoteric. ${ }^{35}$ Diotogenes would then rather address an audience of inexpert readers (or even kings)

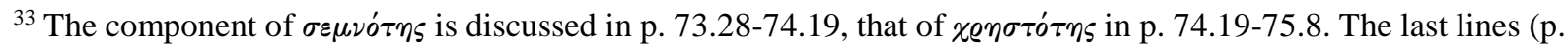

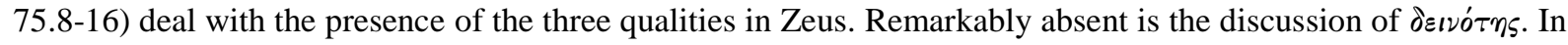
view of the general systematic structure of the argument and the explicit transition formulas (p. 74.19-20: "and on dignity, enough has been said. I will now try to deal with kindliness"), it is almost certain that Diotogenes' added

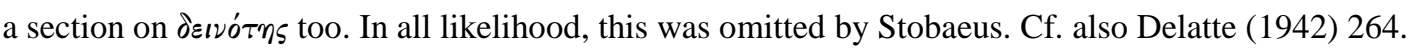

${ }^{34}$ Murray (1970) 280.

${ }^{35}$ Chesnut (1978) 1314. Martens (2003) 172 even argues that the Neopythagorean treatises "seem to be aimed at actual kings" and Thesleff (1961) 101 thinks of Hiero II of Syracuse as Diotogenes' addressee. Squilloni (1991)
} 
in an attempt to introduce them to his Pythagorean philosophy. No compelling arguments can be adduced to decide on this question. ${ }^{36}$ Here as well, equipollence requires $\varepsilon \dot{\lambda} \lambda a ́ \beta \varepsilon ı a$.

The three main qualities of the king can to a certain extent be connected to his three principal

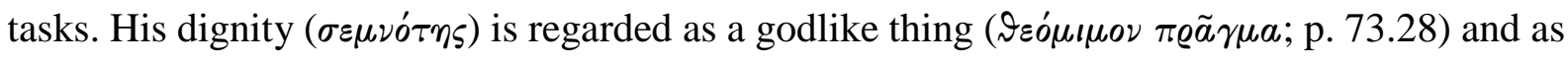
such recalls Diotogenes' insistence of the king's imitation of God and his priestly function. His

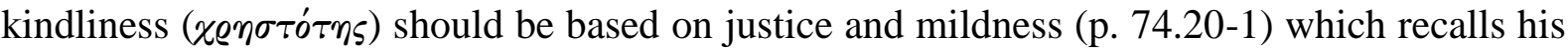

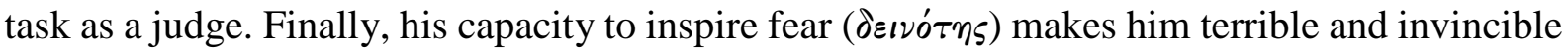
towards his enemies (p. 74.2-3), which of course contributes to his task as a general. Nevertheless, these correspondences do not reveal a simple one-to-one relationship, since the three qualities will presumably prove useful for all the three tasks. They should primarily be understood as the necessary conditions on which the king's credibility and efficiency as a good example for his subjects are based. In that sense, Diotogenes does not confine himself to general theoretical ideals about the king's virtue, but also attempts to examine the presuppositions of these ideals and the way in which they can be realized. Thus, he again adopts an original approach within the extant tradition of Neopythagorean political thinking. ${ }^{37}$ In this fragment,

15 and 185 rather regards them as "opere di critica "per contrarium,"” as indirect criticisms of bad rulers such as Domitian (cf. also p. 189-97).

${ }^{36}$ Typically enough, Thesleff (1961) 72 juxtaposes both alternatives without deciding upon the matter ("I am inclined to think [...] that they were on the whole intended as philosophical propaganda for laymen, or as textbooks in philosophy").

37 That need not imply, though, that Diotogenes did himself conceive of this theory. There can be found a salient

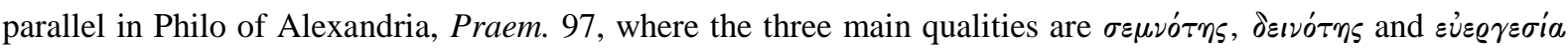

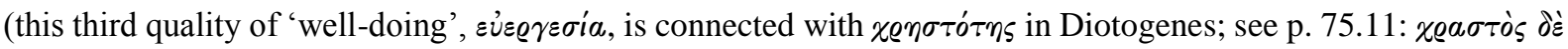

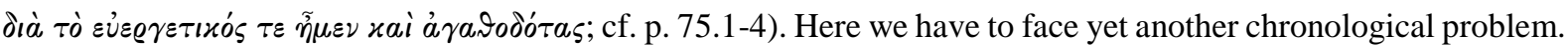
Philo could have been influenced directly by Diotogenes; thus, e.g., Bréhier (1907) 18-23; Goodenough (1938) 90-100 (passim); Martens (2003) 169-70; cf. also Calabi (2008) on the different connections between Philo and 
he especially appears as an open-minded thinker with a keen eye for the demands of concrete political life. ${ }^{38}$

Indeed, one of Diotogenes' most important sources of inspiration for this theory may well have been his familiarity with the career of prominent political leaders from the rich Greek history. Illustrative examples easily come to mind. Pericles, for instance, who according to Plutarch combined reasonableness and gentleness with a dignified behaviour (Per. 39.1), so that the Athenians came to the conclusion that there had never been a character more moderate

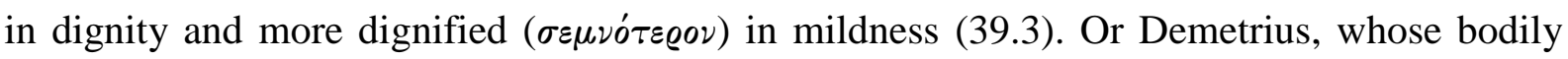
features showed a kingly dignity ( $\beta a \sigma ı \lambda ı x \eta \dot{~} \sigma \varepsilon \mu \nu o ́ \tau \eta \varsigma)$ and whose character was naturally fitted

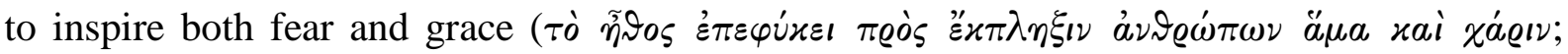
Demetr. 2.3). Examples can easily be multiplied. ${ }^{39}$ Although Diotogenes nowhere mentions such famous statesmen in his extant fragments, these parallels at least show that his political thinking is relevant for the ruler and need not be at odds with the particular difficulties which a politician has to face. Add to this that dignity, kindliness, and the capacity to inspire fear are

\footnotetext{
Ecphantus (these connections, however, may also be regarded as evidence that they both used the same source; thus Thesleff [1961] 70). The clear parallel may also suggest that Diotogenes' philosophy was well-known in the intellectual circles of Alexandria and that Alexandria was the place where these Neopythagorean treatises were written. But all this is very speculative of course.

${ }^{38}$ Contra Murray (1970) 265: "The apparent practicality of Diotogenes in this section is illusory; his main interest is in fitting an already existing triad of Pythagorean vices into a theory of kinship." But Murray does not provide support for his claim, and even if it is true that other Neopythagorean thinkers occasionally dealt with separate qualities in entirely different contexts (cf., e.g., Ps.-Archytas on God's $\sigma \varepsilon \mu \nu$ ó$^{\prime} \eta \varsigma$ in De vir. bon. fr. 2, p. 9.11

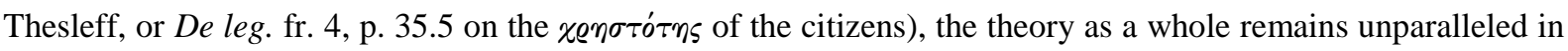
extant Neopythagorean literature.

${ }^{39}$ See for a catalogue of virtues and vices of the heroes of Plutarch's Parallel Lives Bucher-Isler (1972) 11-61 (p.

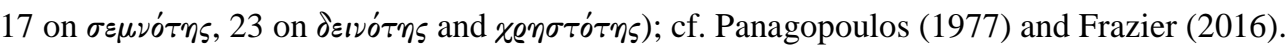


political qualities rather than cardinal virtues. All this suggests that Diotogenes prefers practicable doctrines to abstract theoretical speculations. ${ }^{40}$

This provisional conclusion is further corroborated by other passages in this fragment. Diotogenes, for instance, recommends the ruler to be neither harsh nor contemptible (p. 73.212), a delicate balance that does not reflect an Aristotelian mean but rather well-balanced

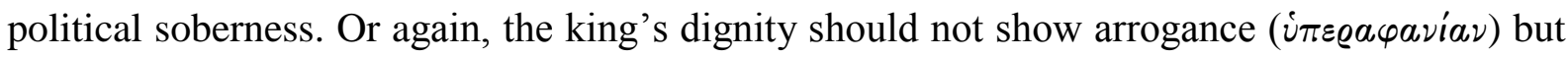
greatness of mind ( $\mu \varepsilon \gamma a \lambda \circ \varphi \varrho \circ \sigma u ́ \nu a \nu) ~(p .74 .11)$, a passage which Tarn even interpreted as a veiled allusion to Demetrius Poliorketes. ${ }^{41}$ Although Tarn's interpretation is built on sand and failed to convince later scholars, ${ }^{42}$ it remains an interesting indicator of the more general practical orientation of this fragment. All in all, Diotogenes' reflections here seem to come closer to the world of the experienced politician who is involved in complicated public affairs than to that of Plato's philosopher-king.

The same holds true for Diotogenes' remarkable position towards the king's greediness $(\pi \lambda \varepsilon o \nu \varepsilon \varkappa \tau i a)$. From a philosophical perspective, such striving for wealth is of course to be strongly rejected as a motivation for a political career. But from the point of view of a politician, such a rigid position was no doubt less evident and we may well presume that many basically agreed with the view of Stratocles and Dromocleides and entered politics as a way to a "golden harvest" (Plutarch, Praec. ger. reip. 798EF). Diotogenes does not ignore this tendency and tries to rationalise it in this passage by arguing that the king needs his possessions in order to benefit his friends, help those in need, and avenge himself upon his enemies (p. 72.30-1). He even goes

\footnotetext{
${ }^{40}$ Cf. Schulte (2001) 147-8. Contra Bréhier (1907) 20: “Cette théorie est une utopie politique, qui néglige fort toutes conditions pratiques.”

${ }^{41}$ Tarn (1948) 410 note 1 . From this hypothesis Tarn even derived some conclusions regarding the date of the fragments. In his view, Diotogenes was a contemporary of Demetrius.

42 Tarn's argument was criticised by Murray (1970) 265 note 2.
} 
so far as to say that greediness concerns the leading part of the soul, since desire is rational (p.

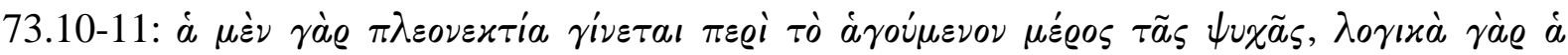

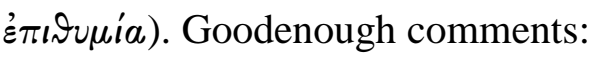

"No more shocking breach of Greek philosophic decorum could be imagined than this

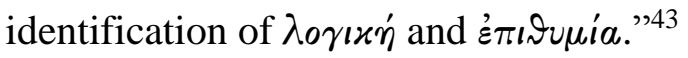

This is absolutely true, and to make things even worse, nothing suggests that Diotogenes is here thinking of a desire for learning and that he recommends the king "to express his avarice in intellectual greed." 44 Nor should we suppose that his view reflects such a degree of philosophical ignorance that could only be expected from an utter ignoramus. It rather characterizes, once again, Diotogenes as a philosopher who does not force the facts in order to fit them with his own theories, but rather prefers to conform his philosophical views to the facts. Confronted with greedy kings, Diotogenes indeed makes the best of a bad job, and we may add that his view is quite creative and ingenious. For while Goodenough is indeed basically correct

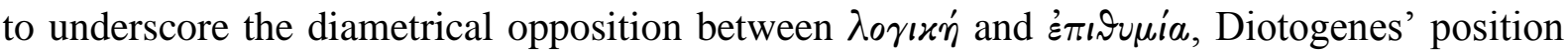
need not be the massive affront to good philosophy, if we read it not as a declaration about desire categorically but as one about this particular species of desire, that is, the greedy or - to use a somewhat less negative term - acquisitive desire for a larger share of material goods than the next person. It does not seem completely bizarre indeed to claim that such a desire has a calculating component to it, and so is not in the same category as the blind urge to pleasure. Thus this striking passage illustrates how far Diotogenes is prepared to go in rationalising a posteriori the morally problematic behaviour of kings. We are indeed on the verge of a

\footnotetext{
${ }^{43}$ Goodenough (1928) 71.

${ }^{44}$ Goodenough (1928) 71.
} 
philosophy that no longer intends to change the king's vices but only to explain them away. Before formulating definitive conclusions about this aspect of Diotogenes' thinking, however, we have to return to the beginning of the first fragment.

4. The opening of fragment 1: weaving the different threads together

Up to now, we have seen how Diotogenes developed an innovative view within the PlatonicoAcademic and Pythagorean tradition by making use of insights borrowed from previous Homer exegesis, and how he also managed to take into account the concrete reality of political life. How, in other words, he combined theoretical erudition with sober-minded pragmatism. At this point, we are ready to turn to the opening section of fragment 1 , where, as we said above, Diotogenes underscores the connection between kingship, justice, and the law. On closer inspection, however, Diotogenes' argument is not immediately evident:

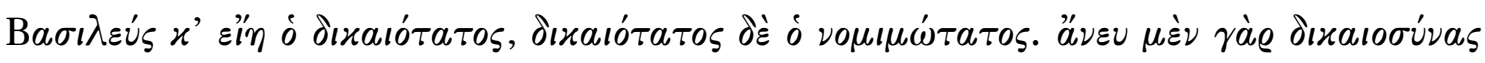

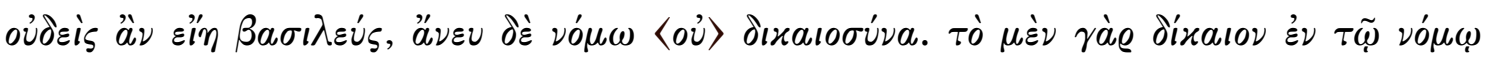

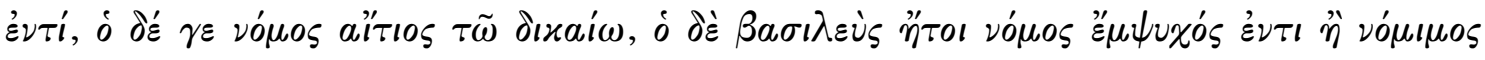

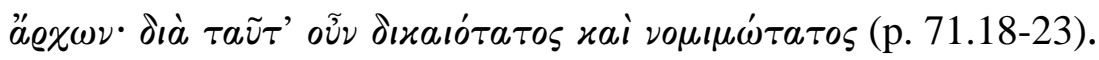

The most just man would be king, and the most lawful would be most just. For without justice no one would be king, and without law [there would be no] justice. For justice is in the law, and the law is the source of justice. But the king is Animate Law, or is a legal ruler. So for this reason he is most just and most lawful.

Diotogenes begins by stating that the most lawful would be the most just, and that the latter

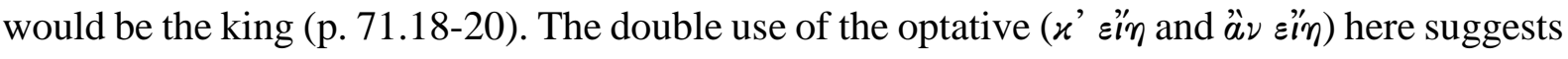


a normative perspective rather than a neutral description of facts. This, then, we may presume, is the philosopher speaking. In the next sentence, this philosophical ideal is further explained ( $\mu \dot{\varepsilon} \nu$ qá@): justice is in the law and the law brings about justice, whereas the king is either

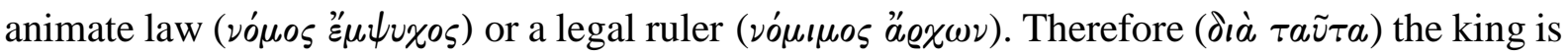

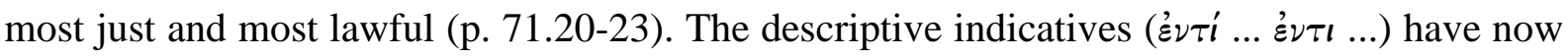
replaced the optatives, and this marks (or masks) a subtle transition. The previous normative perspective now gains further support from what is presented as an apparently straightforward description of real life. Yet this blurring of the distinction between a philosophical normative and a political descriptive position does not deserve an award for logically stringent reasoning. What is going on here?

A possible solution is that Stobaeus has shortened Diotogenes' argument and thus slightly changed its argumentative pattern. This alternative should not be dismissed too easily, for we know that Stobaeus was not afraid of rewriting and subtly changing the text of his source. ${ }^{45}$ Moreover, traces of more significant omissions can be detected elsewhere in Diotogenes' fragments too. ${ }^{46}$ Stobaeus' editorial activity, then, may also account for Diotogenes' awkward argumentation at the beginning of fragment 1, although such an hypothesis cannot be proven and should in my view only be used when no other explanation is available.

Yet in this case, there is perhaps room for an alternative explanation. We may have to do with a subtle strategy of Diotogenes, used to mediate between a philosophical perspective and political reality. Diotogenes here explicitly mentions the doctrine of the 'animate law' (vónos

\footnotetext{
${ }^{45}$ Cf. Piccione (1998) and Roskam (2003) 60-2 on Stobaeus' techniques of excerpting Plutarch, and Curnis (2011) on Stobaeus' reception of Plato.

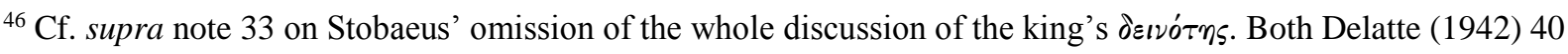
and Thesleff (1965) 73 postulate a lacuna at p. 73.9. Delatte (1942) 41 and 45 detects two other lacunas (at p. 73.15 and 75.8 .
} 
$\varepsilon^{\prime \prime \mu \psi u x o \varsigma) . ~ T h i s ~ w e l l-k n o w n ~ t h e o r y ~ h a s ~ i t s ~ u l t i m a t e ~ r o o t s ~ i n ~ f o u r t h-c e n t u r y ~ p o l i t i c a l ~ t h i n k i n g ~}{ }^{47}$ and was quickly picked up in political circles. Arrian relates how Anaxarchus tried to console Alexander after the murder of Cleitus by reminding him of the view of old sages, who made justice sit by Zeus' throne since anything decided upon by Zeus should be considered just. ${ }^{48}$ The moral of the story is clear of course: anything Alexander has done (even murdering his friend) is to be regarded as just, precisely because he is the king. The potential dangers of this view are obvious of course. A ruler who is no longer accountable for his deeds can do whatever

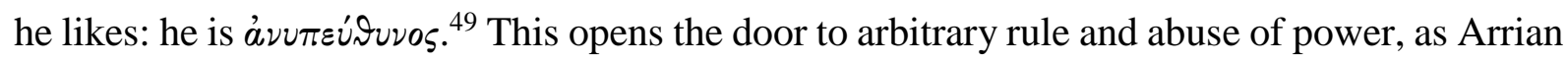
also realised. ${ }^{50}$

If Diotogenes' odd argument at the outset of fragment 1 is seen against this background, we may again detect a clever strategy of approving ideas and ideals shared by politicians while subtly reorienting them towards a more philosophical perspective. Moreover, the philosophical perspective comes first and thus sets the tone. The initial emphasis indeed is on justice and the law, as the use of the article also shows: the idea is not that the king determines justice but that

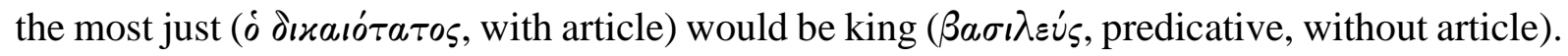
Only after Diotogenes has underlined this philosophical, normative perspective, he

\footnotetext{
${ }^{47}$ Cf., e.g., Aristotle, Pol. 3, 1284a13-14 and 1288a3; EN 4, 1128a31-2 and 5, 1132a21-2; Xenophon, Cyr. 8.1.22;

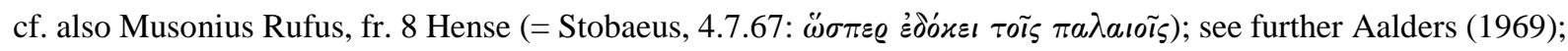
Murray (1970) 251-2 and 273-8; Squilloni (1991) 107-36; Martens (2003) 31-66; on the presence of the doctrine in the works of Philo of Alexandria, see, e.g., Richarson (1957) and Martens (2003) 90-5.

${ }^{48}$ Arrian, An. 4.9.7; the same story is told in Plutarch's Life of Alexander, 52.4-6; cf. also Ad princ. iner. 781 AB.

${ }^{49}$ The term is used by Diotogenes himself at the very end of fragment 1 , and connected with the doctrine of the

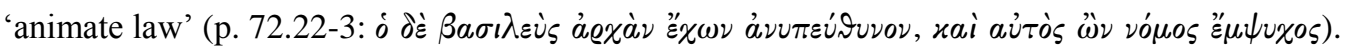

${ }^{50}$ Arrian, An. 4.9.8; similarly again Plutarch, Life of Alexander 52.7 and Ad princ. iner. 781B.
} 
(deceptively) smoothly connects it with the current political view. ${ }^{51}$ In this way, the potential dangers of the doctrine of the king as 'animate law' are at least partly neutralised (and at the same time disguised by an unproblematizing and straightforward $\delta \grave{\iota} \tau a \tilde{v} \tau a)$. Tellingly enough, this entails a different use of the article: whereas the starting point of Diotogenes' argument, as we have just seen, is that the most just ( $\delta$

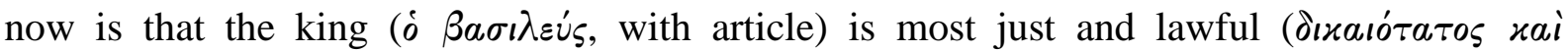

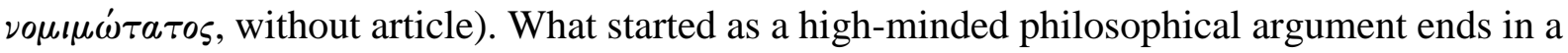
subtle legitimation of the king.

Thus we find in this opening section a new example of Diotogenes' interest in current political praxis, an interest that also became apparent in fragment 2. Here as well, Diotogenes was not content with drawing up philosophical theories in vacuo but kept in mind political reality. Do we also find a trace of the rich tradition of Homer exegesis that was important in the rest of fragment 1 ? This is suggested by an interesting parallel from Dionysius of Halicarnassus that has hitherto been overlooked. In book 5 of his Roman Antiquities, Dionysius tells how the Greek cities were originally ruled by kings. These kings, however, observed the laws, and he

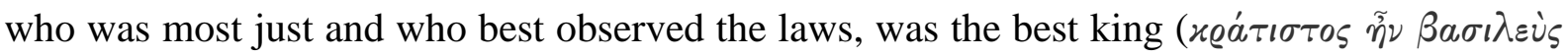

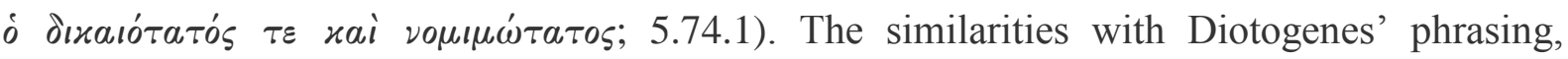
including the strategic use of the article, are striking indeed. Dionysius then continues: this

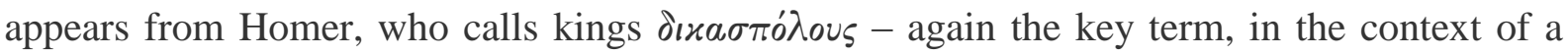
"Homeric theory" of kingship. These, in my view, are too many parallels to be pure coincidence. Of course the condensed fragment from Diotogenes offers too little context to allow for elaborate speculative hypotheses, but given this conspicuous parallel with Dionysius of Halicarnassus, it cannot be excluded that Diotogenes' argument at the beginning of fragment

\footnotetext{
${ }^{51}$ The passage, however, does not throw light on the date of the treatise, since it applies equally to Hellenistic kingdoms and early or later Roman Empire.
} 
1 was not only conditioned by his concern for political praxis but also inspired by his familiarity with traditional Homer exegesis.

\section{Conclusion}

Our reading of the two fragments from Diotogenes' lost treatise On kingship has shown that Diotogenes was more than an epigone parroting traditional ideas. He was a child of the rich tradition, no doubt, but also looked for new paths and innovative approaches. As such, he has his own profile and identity and deserves to be read for his own sake.

As said at the beginning, Diotogenes has often been compared to Ecphantus, usually to his discredit. ${ }^{52}$ The fragments from Ecphantus would contain a more 'mystical' theory of kinship. ${ }^{53}$ He has in mind a sublime king who as it were came down from heaven (fr. 2, p. 81.11-12) as a model providing his subjects with a most holy purification (fr. 2, p. 22.22-3). Compared to this high-minded and exciting ideal, Diotogenes is more prosaic, down-to-earth. He defends analogous views but proves to be more pragmatic. To vary a celebrated ancient saying, he calls down Ecphantus' philosophy from heaven in order to place it firmly in the cities and kingdoms of his day. And this, we may add, need not be the more superficial course. We should not forget

\footnotetext{
${ }^{52}$ See, e.g., Squilloni (1991) 6: "In particolare, se il testo di Stenida è poco più di un frammento, quello di Diotogene assume un andamento lineare, piatto, manualistico, ove le posizioni e le convinzioni personali vengono presentate in modo quasi dogmatico e scolastico, risultando prive di quell'articolazione e di quell'approfondimento teorico che si ritrovano, al contrario, nel trattatello del terzo neopitagorico [viz. Ecphantus]. Le idee che si trovano in Diotogene vengono sviluppate anche nello ps. Ecfanto, ma mentre nel primo esse vengono esposte le une di seguito alle altre, come se l'autore ripetesse diligentemente un copione mandato a memoria, nel secondo si avverte una maggiore e più solida riflessione, la volontà di edificare la teoria del perfetto comando monarchico." The present article goes against such negative general assessments.
}

${ }^{53}$ Cf. also supra note 15 . Thesleff (1961) 70 is more sceptical about such mystical interpretations, and so am I. 
that we are dealing with political philosophy. In such contexts, due attention to concrete praxis may well give evidence of more nuance and more careful thinking, and the more sophisticated political thinker may well be the one who better takes into account the recalcitrant reality of political life. We may recall Cicero's pertinent criticism of Cato the Younger, who spoke in the senate "as if he lived in Plato's Republic instead of Romulus' dregs" (Att. 2.1.8). This, at least, is something that cannot be imputed to Diotogenes.

Moreover, Ecphantus' more 'mystical' perspective, albeit high-minded indeed, risks alienating the politician from him. It suffices to think of the famous anecdote about Trajan and Dio of Prusa told by Philostratus. The emperor said to his eloquent friend who was sitting next to him on a golden chariot: "I do not understand what you are saying, but I love you as myself" (VS 1.7, 488). No matter whether the story is historical or not, ${ }^{54}$ it may well be used to illustrate the gap between the politician's perspective and that of the philosopher. ${ }^{55}$ In this case, Dio was apparently lucky enough to retain the emperor's friendship. Plato, who experienced the same gap in Sicily, was far less fortunate. Again, we begin to see the merits of Diotogenes' more pragmatic stance.

Finally, Diotogenes' general approach may well be perfectly in line with that of Pythagoras himself. This appears from a last scholion on Homer. While commenting upon the first line of the Odyssey, the scholiast relates how Pythagoras always adapted himself to his audience: when he had to speak to children, he used words for children, when he spoke to women, he chose terms that were adapted to them, and when he addressed rulers, he again used a language that

\footnotetext{
${ }^{54}$ See Amato (2014) 99-100 note 13 for further literature on this much debated issue.

${ }^{55}$ Cf. Gangloff (2009) 37.
} 
they could understand ( mind the politician's point of view, Diotogenes obviously follows in the steps of his distinguished master.

The result of this short exercise in synkrisis between the two Neopythagoreans is not that Diotogenes was a better thinker than Ecphantus, not even that he was a more subtle political thinker. Both authors had their own qualities. What the comparison has shown, however, is that Diotogenes should not be regarded as a minor, less interesting figure who is eclipsed by the more brilliant Ecphantus or by other Neopythagoreans. He was a clever and sophisticated thinker and Stobaeus was right to juxtapose fragments from his works to those of his fellow Neopythagoreans.

6. Works quoted

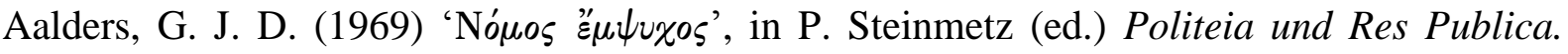
Beiträge zum Verständnis von Politik, Recht und Staat in der Antike, Wiesbaden, 315-29. — (1975) Political Thought in Hellenistic Times, Amsterdam.

Amato, E. (2014) Traiani praeceptor. Studi su biografia, cronologia e fortuna di Dione Crisostomo, Besançon.

Andorlini, I., Luiselli, R. (2001), 'Una ripresa di Diotogene Pitagorico, Sulla regalità, in PBingen 3 (encomio per Augusto?)', ZPE 136, 155-66.

Asmis, E. (1991) 'Philodemus's Poetic Theory and On the Good King According to Homer', ClAnt 10, 1-45.

\footnotetext{
${ }^{56}$ See on this testimony esp. Cornelli (2013) 32-33 and Mota (2013) 108-109 (connecting Pythagoras with the Homeric Odysseus and with the rhapsodic tradition); cf. also Zucconi (1970) 493-494; Riedweg (2005) 12-13 and Zhmud (2012) 46-47.
} 
Balot, R. (2009) A Companion to Greek and Roman Political Thought, Malden.

Bonazzi, M. (2013) 'Eudorus of Alexandria and the 'Pythagorean' pseudepigrapha', in G. Cornelli, R. McKirahan, C. Macris (eds.) On Pythagoreanism, Berlin - Boston, 385-404.

Bréhier, É. (1907) Les idées philosophiques et religieuses de Philon d'Alexandrie, Paris.

Bucher-Isler, B. (1972) Norm und Individualität in den Biographien Plutarchs, Bern Stuttgart.

Buffière, F. (1973) Les mythes d'Homère et la pensée grecque, Paris.

Calabi, F. (2008) God's Acting, Man's Acting. Tradition and Philosophy in Philo of Alexandria, Leiden - Boston.

Centrone, B. (1994) 'Diotogène', in R. Goulet (ed.) Dictionnaire des philosophes antiques. II: Babélyca d'Argos à Dyscolius, Paris, 886.

— (2014) 'The Pseudo-Pythagorean Writings', in Huffman (2014) 315-40.

Chesnut, G. F. (1978) 'The Ruler and the Logos in Neopythagorean, Middle Platonic, and Late Stoic Political Philosophy', in ANRW 2.16.2, Berlin - New York, 1310-32.

Cornelli, G. (2013) In Search of Pythagoreanism. Pythagoreanism as an Historiographical Category, Berlin - Boston.

Curnis, M. (2011) 'Plato Stobaeensis. Citazioni ed estratti platonici nell'Anthologion', in G. Reydams-Schils (ed.) Thinking Through Excerpts. Studies on Stobaeus, Turnhout, 71-123.

Daris, S. (2000) 'Frammento di materia medica', in H. Melaerts (ed.) Papyri in honorem Johannis Bingen Octogenarii (P.Bingen), Leuven, 15-16.

Delatte, L. (1942) Les traités de la Royauté d'Ecphante, Diotogène et Sthénidas, Liège - Paris. Desmond, W. (2011) Philosopher-Kings of Antiquity, London.

Dillon, J. (2014) 'Pythagoreanism in the Academic Tradition: The Early Academy to Numenius', in Huffman (2014) 250-73.

Dorandi, T. (1982) Filodemo. Il buon re secondo Omero. Edizione, traduzione e commento, 
Napoli.

Fish, J. (2002) 'Philodemus' On the Good King According to Homer: Columns 21-31', CErc $32,187-232$.

Fraser, P. M., Matthews, E. (1987-2013) A Lexicon of Greek Personal Names, Oxford.

Frazier, F. (2016) Histoire et morale dans les Vies Parallèles de Plutarque, Paris [second edition].

Gangloff, A. (2009) 'Le sophiste Dion de Pruse, le bon roi et l'empereur', RH 311, 3-38.

Giannantoni, G. (1982) 'Il pensiero politico greco dopo Alessandro Magno', in L. Firpo (ed.) Storia delle idee politiche, economiche e sociali. Volume primo: L'Antichità classica, Torino, 331-71.

Goodenough, E. R. (1928) ‘The Political Philosophy of Hellenistic Kingship', YClS 1, 53-102.

_ (1938) The Politics of Philo Judaeus. Practice and Theory. With a general bibliography of Philo by H. L. Goodhart and E. R. Goodenough, Hildesheim.

Huffman, C. A. (ed.) (2014) A History of Pythagoreanism, Cambridge.

Kagan, D. (1965) The Great Dialogue. History of Greek Political Thought from Homer to Polybius, New York - London.

Kahn, C. H. (2001) Pythagoras and the Pythagoreans. A Brief History, Indianopolis Cambridge.

Martens, J.W. (2003) One God, One Law: Philo of Alexandria on the Mosaic and Greco-Roman Law, Boston - Leiden.

Mota, M. (2013) 'Pythagoras Homericus: Performance as Hermeneutic Horizon to Interpret Pythagorean Tradition', in G. Cornelli - R. McKirahan - C. Macris (eds.), On Pythagoreanism, Berlin - Boston, 103-115.

Muccioli, F. (2002) 'Pitagora e i pitagorici nella tradizione antica', in R. Vattuone (ed.) Storia greci d'occidente, Bologna, 341-409. 
Murray, O. (1965) 'Philodemus on the Good King according to Homer', JRS 55, 161-82.

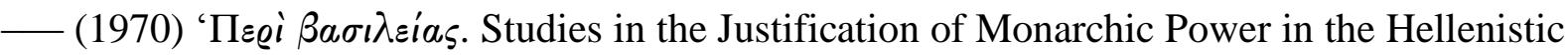
World', $\mathrm{PhD}$ thesis, University of Oxford.

— (2007), 'Philosophy and Monarchy in the Hellenistic World', in T. Rajak e.a. (eds.), Jewish Perspectives on Hellenistic Rulers, Berkeley - Los Angeles - London, 13-28.

Panagopoulos, C. (1977) 'Vocabulaire et mentalité dans les Moralia de Plutarque', DHA 3, 197-235.

Piccione, R. M. (1998), 'Plutarco nell'Anthologion di Giovanni Stobeo', in I. Gallo (ed.) L'Eredità culturale di Plutarco dall'Antichità al Rinascimento. Atti del VII Convegno plutarcheo, Milano - Gargnano, 28-30 maggio 1997, Napoli, 161-201.

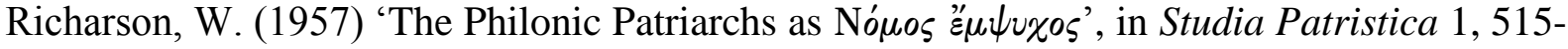
25.

Riedweg, C. (2005) Pythagoras. His Life, Teaching, and Influence, Ithaca - London.

Roskam, G. (2003) 'Being the Physician of one's own Soul. On a Plutarchan Fragment on Anger (fr. 148 Sandbach)', Humanitas 55, 41-62.

Salkever, S. (2009) The Cambridge Companion to Ancient Greek Political Thought, Cambridge.

Schulte, J. M. (2001) Speculum regis. Studien zur Fürstenspiegel-Literatur in der griechischrömischen Antike, Münster - Hamburg - London.

Squilloni, A. (1991) Il concetto di 'regno' nel pensiero dello ps. Ecfanto. Le fonti e i trattati $\pi \varepsilon \varrho i \beta a \sigma i \lambda \varepsilon i a \varsigma$, Firenze.

Tarn, W. W. (1948) Alexander the Great. II: Sources and Studies, Cambridge.

Thesleff, H. (1961) An Introduction to the Pythagorean Writings of the Hellenistic Period, Abo.

— (1965) The Pythagorean Texts of the Hellenistic Period, Collected and Edited, Abo.

Virgiglio, B. (2003) Lancia, diadema e porpora. Il re e la regalità ellenistica, Pisa. 
Wellmann, E. (1903) ‘Diotogenes’, RE 5.1, Stuttgart, 1150.

Zeller, E. (1903) Die Philosophie der Griechen in ihrer geschichtlichen Entwicklung. Dritter Theil, Zweite Abtheilung: Die nacharistotelische Philosophie, zweite Hälfte, Leipzig.

Zhmud, L. (2012) Pythagoras and the Early Pythagoreans, Oxford.

Zucconi, M. (1970) 'La tradizione dei discorsi di Pitagora in Giamblico, Vita Pytagorica 3757', RFIC 98, 491-501. 